\title{
Influence of Moderating Effect of People Strategy on Startegic Human Resources Functions on Organizational Performance of Insurance Industry of Sri Lanka
}

\author{
By Chandrasiri Gannile, Mohd ShukriAb Yajid, Ali Khatibi \\ $\&$ Dr. Ferdous Azam
}

Abstract- People strategy simply aim to establish best practice in each of the HR policy areas, there have been attempts to describe people strategy as an internally coherent set of HR policies and practices. This endeavor has proven to be both difficult and elusive. As one might expect, there appears to be no one single ideal type of people strategy with a set of HR policies and practices that can be adopted by organizations seeking to manage their people more strategically (Lynda Gratton, Catherine Truss, 2003). People of a firm is a strategic asset and a very important element and the backbone of every firm (Anam, Rashi, Rad \& Mizana, 2013). People strategy plays a critical role in harmonizing strategic human resource management implementation in an organization (Linda Gratten, Catherine Truss, 2012).

Keywords: people strategy, HR strategies, firm performance, HR policies, skills, staff, shared values/style.

GJMBR-A Classification: JEL Code: 015

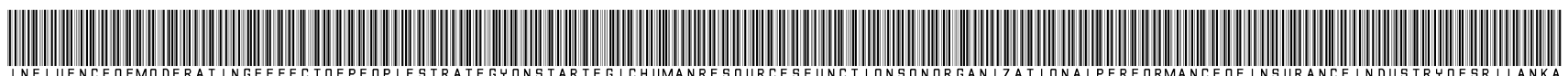

Strictly as per the compliance and regulations of:

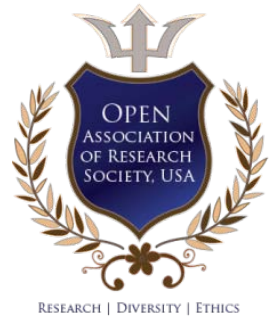

(C) 2021. Chandrasiri Gannile, Mohd ShukriAb Yajid, Ali Khatibi \& Dr. Ferdous Azam. This research/review article is distributed under the terms of the Attribution-NonCommercial-NoDerivatives 4.0 International (CC BY-NC-ND 4.0). You must give appropriate credit to authors and reference this article if parts of the article are reproduced in any manner. Applicable licensing terms are at https://creativecommons.org/licenses/by-nc-nd/4.0/. 


\title{
Influence of Moderating Effect of People Strategy on Startegic Human Resources Functions on Organizational Performance of Insurance Industry of Sri Lanka
}

\author{
Chandrasiri Gannile ${ }^{\alpha}$, Mohd ShukriAb Yajid ${ }^{\sigma}$, Ali Khatibi ${ }^{\circ} \&$ Dr. Ferdous Azam ${ }^{\omega}$
}

\begin{abstract}
People strategy simply aim to establish best practice in each of the HR policy areas, there have been attempts to describe people strategy as an internally coherent set of HR policies and practices. This endeavor has proven to be both difficult and elusive. As one might expect, there appears to be no one single ideal type of people strategy with a set of HR policies and practices that can be adopted by organizations seeking to manage their people more strategically (Lynda Gratton, Catherine Truss, 2003). People of a firm is a strategic asset and a very important element and the backbone of every firm (Anam, Rashi, Rad \& Mizana, 2013). People strategy plays a critical role in harmonizing strategic human resource management implementation in an organization (Linda Gratten, Catherine Truss, 2012). Converting Human Resources policies into action is absolutely necessary and important in delivering the people management functions. There is a real gap between well written down HR policies and implementation of those policies to make it real applications in terms operational people management practices in an organization (Linda Gratten, Catherine Truss, 2012). The managers and line management personnel need to realistically follow human resources policy guidelines when appraising firm's performance as well as employee performance without deviations whereas mediocre managers are lenient against applicable methods of both organization wide and employee wide performance evaluations. This hinders organizations in identifying real performance gaps in the organization (Linda Gratten, Catherine Truss, 2012; Lynda Gratton, Catherine Truss, 2003) The researcher focuses on mainly on existing body of knowledge in the research area, focusing on how people of a business firm influence the performance of the firm and what has been researched in the intended area.
\end{abstract}

Keywords: people strategy, HR strategies, firm performance, HR policies, skills, staff, shared values/style.

Author a: Head of Human Resources and Administration, People's Insurance PLC, Sri Lanka, PhD Candidate, Graduate School of Management, Management \& Science University, Malaysia.

e-mail:gannile1@gmail.com

Author $\sigma$ p: Prof. Dr., Graduate School of Management, Management \& Science University, Malaysia.

Author w: Graduate School of Management, Management \& Science University, Malaysia.

\section{INTRODUCTION}

- This study focusses on how key strategic HR functions go hand in hand in a business firm with its people or human resources as the key driver of the firm with other resources both tangible and intangible then discuses about key strategic HR functions and their impact on people strategy. The research further emphasizes and explains the relevant and important of SHRM practice and specific business models. The human resource management strategy is a set of inner-organizational people management strategies. The effective application of the human resource management strategy in different situations can help enterprises use employees effectively for the completion of organizational targets. According to definitions of the human resource management strategy made by many scholars and experts, many researchers attempted to set types of the people management strategy (Fu-Jin Wang, Shieh Chich-Jen and Tang MeiLing, 2010). Every firms' top priority is to manage the human resources. The level of the productivity and the efficiency of employees should be increased to take maximum contribution (Gamage \& Imbulana, 2013).

After identification of variables that can operate in a situation and the relationships among these can be established. The research is based on the theoretical foundation which is logically developed describes and elaborated network of connections among the variables.

The dependent variable is organizational performance which is the variable of primary interest whilst explaining the dependent variable with three independent variables, staff, skills shared values/styles and people strategy as the moderating variable of the study.

Staff is one of the most valuable resource of every organization that drives suitable recruitment, selection, placement, development appraisals, rewarding, recognition moral and initiation and retention of staff positively impacts the organizational performance.

Skills are the abilities that firm's employee performs to the expectations of management which 
includes capabilities and competencies. Skills positively impacts on organizational performance.

Shared values/style refer to overall impact of processes and system on the organization with regard to employees and managers and company management plan which is congruent and being implemented. Shared values/style positively impacts the organizational performance.

\section{a) Insurance industry}

Insurance industry is a people based, knowledge driven business that provides unique financial services to the growth and development of every economy. Such specialized financial services ranging from the underwriting of risks inherent in economic entities and the mobilization of large amount of funds through premiums for long term investments. The risk absorption role of insurers promotes financial stability in the financial markets and provides a sense of peace to economic entities. The insurance companies' ability to cover risk in the economy hinges on their capacity to create profit or value for their shareholders. A well- developed and evolved insurance industry is a boon for economic development as it provides longterm funds for development (Charumathi, 2012 and Agiobenebo and Ezirim, 2002). People are a critical deciding variable factor for firm's performance, actively involved by its people in relation to firm's earnings, profits, appreciations in value as evidenced by the rise in the entity's share price. In insurance, performance is normally expressed in net premiums earned, profitability from underwriting activities, annual turnover, returns on investment and return on equity. These measures can be classified as profit performance measures and investment performance measures. Profit performance includes the profits measured in monetary terms. Simply, it is the difference between the revenues and expenses. These two factors, revenue and expenditure are in turn influenced by firm-specific characteristics, industry features and macroeconomic variables. Investment performance can take two different forms. One the return on assets employed in the business other than cash, and two, the return on the investment operations of the surplus of cash at various levels earned on operations (Asimakopoulos, Samitas, and Papadogonas, 2009).

\section{STAFF}

A firm is directly linked to the performance of those who work for that business. By the same principal, under-achievement can be a result of organization failures. Because hiring the wrong people or failing to anticipate fluctuations in hiring needs can be costly, it is important that conscious efforts are put into human resource planning (Biles \& Holmberg, 1980; Djabatey, 2012). It has also been argued that in order for the enterprise to build and sustain the competitive advantage, proper staffing is critical (Djabatey, 2012). Thus, recruitment and selection have become imperative in organizations because individuals need to be attracted on a timely basis, in sufficient numbers and with appropriate qualifications. Empirical research has emphasized that the adaption of organizational human resources capabilities on firm performance create competitive edge (Kogo and Linda, 2018).

Qualified staff is one of the most valuable resources of every organization. The ability of an organization to implement company strategic plan is largely dependent on its ability to recruit, select, place, appraise and develop appropriate employees. So, it's crucial for firms to exploit proper methods to recruit and retain qualified employees, and nurture, develop and maintain a high level of employees' morale and motivation among them (Kim, Lee, \& Gosain, 2005; Metaxiotis, Zafeiropoulos, Nikolinakou, \&Psarras, 2005; Skok \& Legge, 2002; Umble et al., 2003; Verville et al., 2005; Willcocks \& Sykes, 2000). Motivation flourishes employee output. Employee motivation is a critical aspect at the organization which leads to the performance and survival (Mohammed Sani Abdullahi, Zainab Lawan Gwadabe \& Mu'awiyya Bature Ibrahim, 2018)

Dimensions of staff are mostly considered in one of ways. At the hard end of the dimensions, elements, appraisals systems, pay scales, formal training programs, at the soft end, it is about staff morale, attitude, motivation and behavior (Kogo and Linda, 2018).

Firms that use people in the best manner best, rapidly shift their executives into positions with proper responsibility though various live support mechanism like assigned mentors, fast-track programs, and carefully articulated opportunities for reaching to top management are of their people management approach (Anam, Rashi, Rad \& Mizana, 2013).

A firm is directly linked to the performance of those who contribute for that business. In the same manner, under-performance can be a cause of firm's failures. Whereas recruiting unmatched people or inability to anticipate fluctuations in hiring needs can be expensive therefore it is important that care full efforts are madeinto human resource planning (Biles \& Holmberg, 1980; Djabatey, 2012). Similarly, it is argued that in order to build and sustain the competitive advantage, proper staffing is crucial for the organization t (Djabatey, 2012). Thus, recruitment and selection have become imperative in the firm because individuals need to be attracted on a timely basis, in sufficient numbers with appropriate qualifications.

Firms staff as a pool of resources to be nurtured, developed, guarded, and allocated is one of the many ways to turn the "Staff" dimension into firms performance dimension with management practice (Juilen \& Phillips, 2014). 


\section{a) Skills}

Skills development and development assets are important as a subsystem within the many activities of $\mathrm{HR}$ functions. It is further highlighted that human resources are the most dynamic element of all resources of any firm (Riggio, 2015). Hence adequate focused attention and significance must be paid to train employee skills development and capabilities in the organization. Aamodt (2007) opine that skills training is the preparation of individuals in a firm for a task, job or an occupation by getting specific skills needed. Training is usually inbuilt to the job rather than personal (Armstrong, 2003). Training is the use of integrated and planned instruction mechanism to encourage learning (Armstrong, 2003).Training enables the implementation of formal processes to instill knowledge and help employees to get the needed skills to satisfactorily carry out their duties. The emphasis on training is drawn to practical skills which is concerned with the adoption and utilization of techniques and processes (Cole,2005; Okoh, 2005). A. L. Damoe et al. (2012) asserted in their study that highly skillful and knowledgeable staff is very necessary for the improvement of the organization. Employee skills which represents employee designation wise competencies critically add value for increasing service delivery performance in a firm (Hisham MakkiHanafi, Siddig Balal Ibrahim, 2019).

Workforce's skills and potential behavior with the strategic priorities is aligned with the firm has increasingly been referred to as Strategic Human Resource Management (SHRM) (Wright, P. M., \& Ulrich, M. D., 2017). Training also has impact on the return on investment since the organizational performance depends on employee performance because human resource capital of organization plays an important role in the growth and development of such organization (Kenny S., Victoria, 2019).

Human Resource Development plays significant role for a firm to compete with a changing business environment and ultimate effect goes to firm's performance (Kenny S., Victoria, 2019). A clear line of sight is there between unique and difficult-to-transfer employee skills and the firm's strength to continuously outperform competitors in the marketplace (Kryscynski, D., \& Ulrich, D., 2015). Firms invest huge amount on the human resource capital because the performance of human resource will ultimately increase the performance of the employee and the organization. Performance is a major multidimensional construct aimed to achieve results and has a strong link to strategic goals of an organization (Raja, Furgual \& Mohammed, 2011; Gambo, 2018).

\section{b) Shared Values/Style}

Shared values/ style are defined as guiding principles and elementary thoughts whereas a firm's business is built up on (Peters \& Waterman, 1982). This term refers to the degree to which a key management team recognizes and trusts that the company goals (Pinto et al., 1993) as well as super ordinate goals enhance the likelihood of finding good quality solutions in a timely manner that should be organized in a manner that enables the management team to describe in detail what the company strives to achieve (Chien et al., 2008). Three dimensions are identified here as affecting factors on shared values:

Shared beliefs refer to a belief about the overall impact of processes and systems on the organization with employees and managers (Amoako-Gyampah \& Salam, 2004). It understands that if employees have a shared knowledge on Management plan which is being implemented, it is likely to foster trust and cooperation among them that can lead to implementation success (Amoako-Gyampah \& Salam, 2004). Hence, it is important for managers to be aware early in firm's plans whether different people of the organization have several opinions on the shared beliefs about the concept.

Under firm's style, organizational leadership play a critical role in visioning the people strategy of the firm, Employee performance and leadership competencies are the key factors that contributet oorganizational performance. Competent leaders influence their fellow staff as well as Organizational leaders play a vital role in the achievement of organizational goals and objectives by creating a conducive environment that influences employees' behaviors, attitudes, and motivations (BabcockRoberson and Strickland, 2010); Mastrangelo et al., 2014).

The firm's success depends on the competency of its leaders and the organizational culture as well as the beliefs and values of an organization's influence firm's performance (Soebbing et al., 2015). The competency of a leader is best measured by the performance of the firm. Competent leadership is built upon various variables and characteristics, including values, knowledge, intellectual drive, ethics, charisma, creativity, self-confidence, and courage (Pradhan and Pradhan, 2015).

\section{c) Organizational Performance}

The business firms face a volatile market situation. In order to create and sustain competitive advantage in this type of environment, organizations must continually improve their business performance. Increasingly, organizations are recognizing the potential of their human resources as a source of sustained competitive advantage. Linked to this, more and more organizations are relying on measurement approaches, such as workforce scorecards, in order to gain insight into how the human resources in their organizations add value (lqbal, A., 2019).

The increasing trend in measurement is further stimulated by a growing number of studies that show a 
positive relationship between human resource management and organizational performance. The relationship between HRM and firm performance has been a hotly debated topic over the last two decades, with the great bulk of the primary scientific research coming from the USA and, to a lesser extent.

In a world in which financial results are measured, a failure to measure human resource policy and practice implementation dooms this to secondclass status, oversight, neglect, and potential failure. The feedback from the measurements is essential to refine and further develop implementation ideas as well as to learn how well the practices are actually achieving their intended results (Combs, J., Liu, Y., Hall, A., \& Ketchen, D., 2006).

\section{ili. Methodology}

The methodology consists of a research framework, research process, research design, defining of variables, sampling framework, sources of the questionnaire, providing hypotheses to be tested based on the literature, theoretical and empirical findings. The information sources, types and methods of data analysis were included.

This research study examine the impact of moderating effect of people strategy on strategic human resource management functions on organizational performance of insurance companies in Sri Lanka as well as examining whether the impact of statistical practices on organizational performance is contingent on organizations' people factor. A multi-respondent survey of 29 licensed insurance companies was undertaken and data collected was subjected to correlation analysis as well as descriptive statistics, applying SPSS and AMOS statistical tools in pursuance of the study's stated objectives. The stated research area was measured through a well administered questionnaire which was developed based on SHRM functions and performance dimensions, systems, staff, skills, HR statistics, and organizational performance. The study is based on literature survey, thus it is a deductive research. The study is mainly based on primary data. The population is employees of insurance companies. The sample consists of 576 which is adequate for the study. The data was collected via a structured questionnaire. The questionnaire was shared to the respondents with online link, Google form and by email, depending on the situational requirements.

\section{a) Research Model and Hypotheses}

Whilst the researcher focusses on this research study to examine the influence of impact of moderating effect of people strategy on strategic human resource management functions on organizational performance, following is the research model designed for the study. The dependent variable is considered as the organizational performance. The research model consists of eight independent variables such as strategy, structure, systems, staff, skills, shared values, style, statistics and people strategy as one moderating variable whereas researcher has taken specific research study on the above area of research. As depicted in Figure 3.1 independent variables are mainly derived from Mackency model (2007).

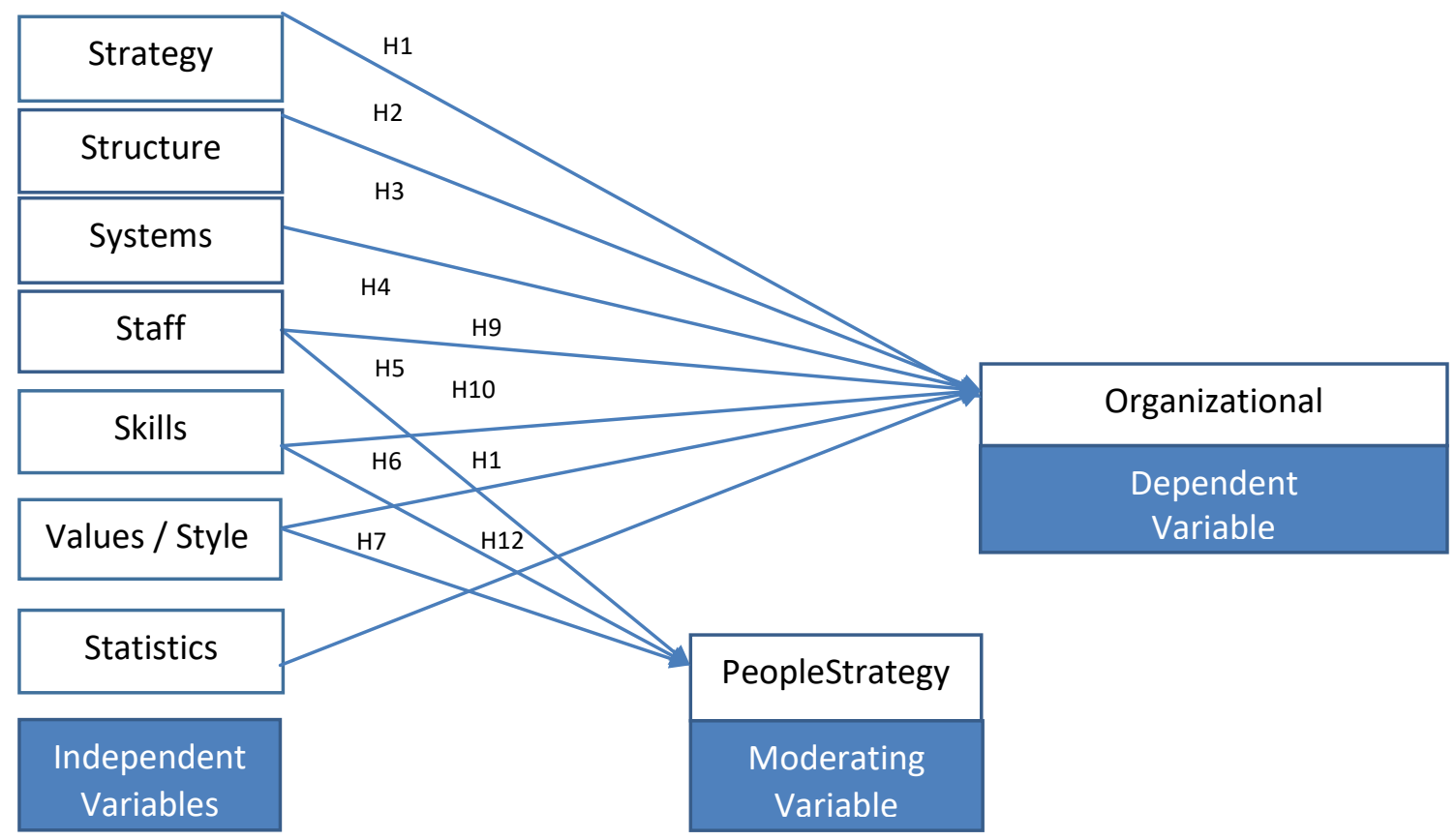

(Source: Developed by the Researcher)

Figure 3.1: Conceptual Framework 
The figure 3.1, Conceptual Framework consists of eight independent variables as indicated above, strategy, structure, systems, staff, skills, shared values, style, and statistics and people strategy as one moderating variable.

\section{b) Research Hypothesis}

The researcher brings forward hypothesis which is a tentative explanation made by the researcher on what the researcher considers the outcome of the research will be. The hypotheses are derived from the relevant literature and the scientific approach for the research, generally being, after presenting the research hypotheses. In the context of moderating effect of people strategy, SHRM factors and organizational performance research, commonly several hypotheses are tested in a large number of research studies with different frameworks. Following this, hypotheses are drawn according to the research questions and the objectives of the study.

\section{c) Major Hypothesis in the Analysis}

H1: There is a significant positive relationship between people strategy and organizational performance.

H2: The relationship between staff and skills is moderated by people strategy.

H3: The relationship between shared value / style is moderated by people strategy.
The research objectives of this theses are aligned with the hypothesis developed on the theoretical framework which is presented in figure 3.1.

\section{Analysis of Data}

The analysis was based on the statistical analysis, findings of the survey instrument, data analysis and the final results of the research study. This would be depicted in charts and relevant tables.

The insurance industry talent market is more competitive than ever with the rise of new technologies, climbing costs of recruitment and increasing demand for new skills. To be successful in the rapidly changing market, it is needed to rethink the approach to statistical analysis on moderating effect on SHRM contribution and Organizational Performance. The Statistical Package of Social Science (SPSS) 21 and Analysis of Moment Structure (AMOS) 21 packages were used to analyze the quantitative data. Structural equation method is reviewed including the results of the confirmatory factor analysis of each construct. then, the validity, reliability and standardized residuals of each construct are explained. Measurement models as well as structural models of the study are submitted. Hypotheses testing are discussed and presented. The moderating effects of people strategy are also presented respectively.

Table 4.1: Inter-item Correlation Reliability

\begin{tabular}{|c|c|c|c|c|}
\hline \multirow[t]{2}{*}{ Concept } & \multirow[t]{2}{*}{ Question } & \multicolumn{2}{|c|}{ No. of items } & \multirow[t]{2}{*}{ Cronbach's Alphe } \\
\hline & & Initial & Final & \\
\hline Strategy & 5 & 6 & 4 & .708 \\
\hline Structure & 6 & 5 & 5 & .798 \\
\hline Systems & 4 & 3 & 4 & .858 \\
\hline Staff & 8 & 8 & 5 & .712 \\
\hline Skills & 8 & 8 & 4 & .846 \\
\hline HR Statistics & 9 & 9 & 8 & .752 \\
\hline Shared Values/Style & 10 & 4 & 6 & .710 \\
\hline People Strategy & 14 & 10 & 7 & .894 \\
\hline Organizational Perf(OP) & 12 & 12 & 7 & .871 \\
\hline
\end{tabular}

a) Staff

There are five items (SAF1, SAF2, SAF3, SAF4, SAF5) in the SAF construct. The descriptive summary and Inter-item correlations values for items in SAF construct are depicted in Table 4.1 the Cronbach's alpha for SAF construct was 0.712, above the recommended cut-off 0.70 (De Vellis, 2003). The Inter item correlation matrix revealed the highest correlation values for SAF construct items were more than 0.3 (Hair, et al., 1998). As a result, no items were removed from the SAF construct. 


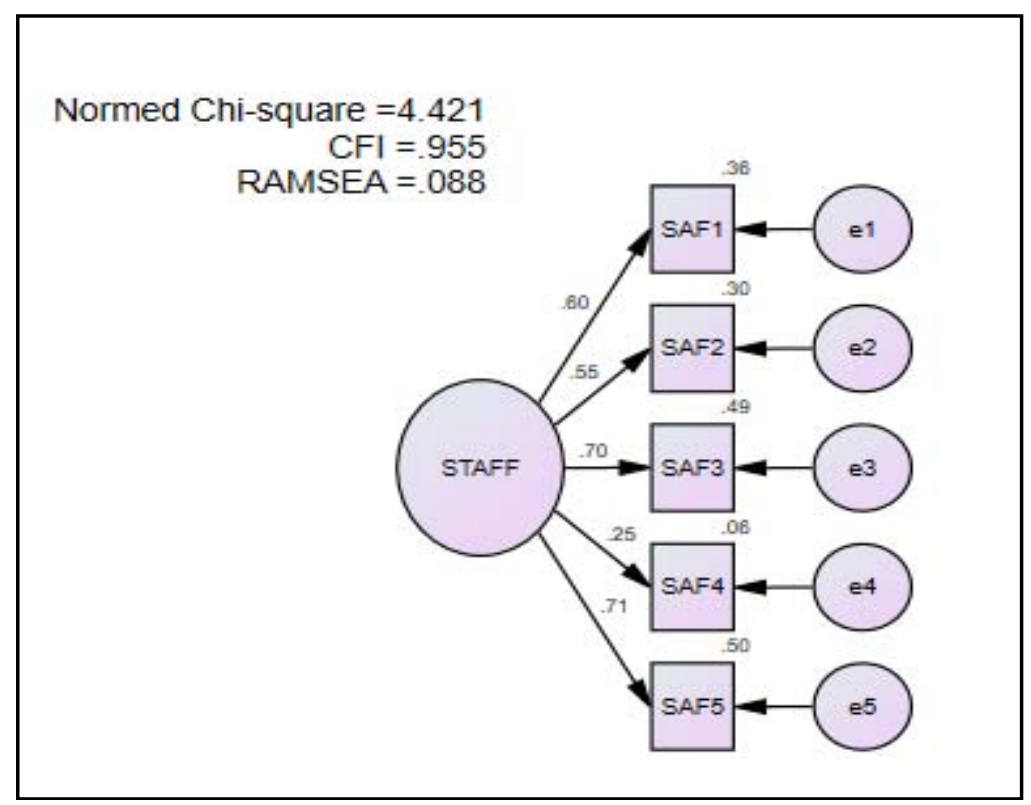

Figure 3.2: Initial measurement model for constructs of staff.

There are five items (SAF1, SAF2, SAF3, SAF4, SAF5) in the SAF construct. The descriptive summary and Inter-item correlations values for items in SAF construct are depicted in Table 3.8.

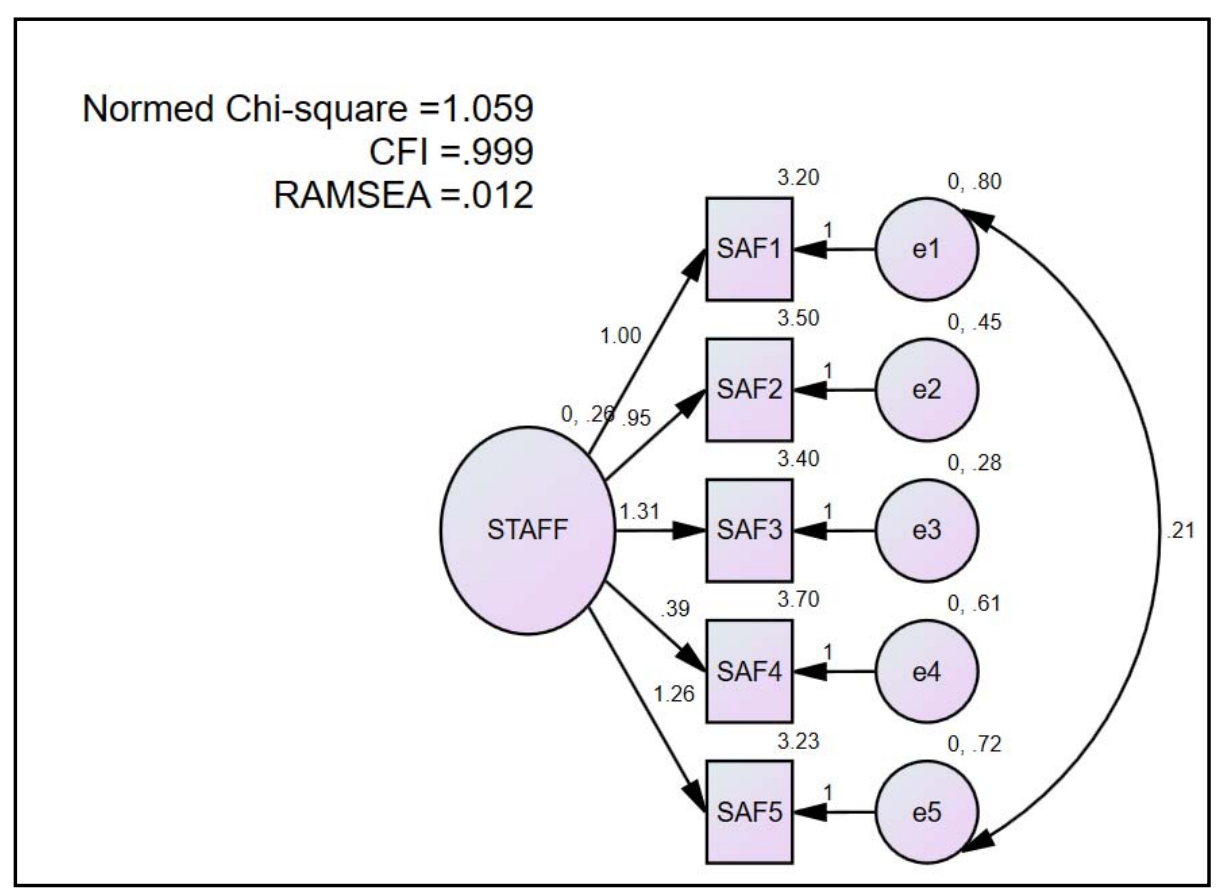

Figure 3.3: Final model of the SAF construct

The figure 3.3, final model of the SAF constructis aligned with the data evidenced by the Normed Chi-square, CFI, and RMSEA were in the desired value (Chinna, 2013). Further, factor loading of all the items was above .5, indicating adequate Individual item reliability (Hair, etal1995).

Then the final model of the SAF construct aligned with the data evidenced by the Normed Chi-
The fit indices indicated a good fit (CMIN/DF < 3.00, $\mathrm{CFI}<0.3$, and; RMSEA $<0.08$ ) in the Initial measurement model for SAF construct. 
Table 4.2: Factor loading of all items SAF

\begin{tabular}{|c|c|c|c|c|c|c|c|}
\hline & & & Estimat.e & S1.E. & C.R. & P & Label \\
\hline SAF1 & $<---$ & F6 & 1.000 & & & & \\
\hline SAF2 & $<---$ & F6 & .733 & .087 & 8.453 & $\star \star \star$ & par_1 \\
\hline SAF3 & $<---$ & F6 & .959 & .099 & 9.677 & $\star \star \star$ & par_2 \\
\hline SAF4 & $<---$ & F6 & .329 & .074 & 4.421 & $\star \star \star$ & par_3 \\
\hline SAF5 & $<---$ & F6 & 1.215 & .125 & 9.709 & $\star \star \star$ & par_4 \\
\hline
\end{tabular}

b) Skills

There are four items (SKI3, SKI4, SKI5, SKI6) in the SKI construct. The descriptive summary and Interitem correlations values for items in SKI construct are depicted in Table 4.1.The Cronbach's alpha for SKI construct was 0.846 , above the recommended cut-off 0.70 (De Vellis, 2003). The Inter item correlation matrix revealed (Table 4.1) the highest correlation values for SKI construct items were more than 0.3 (Hair,et al.,1998).

Normed Chi-square $=1.332$

$\mathrm{CFI}=.999$

RAMSEA $=.027$

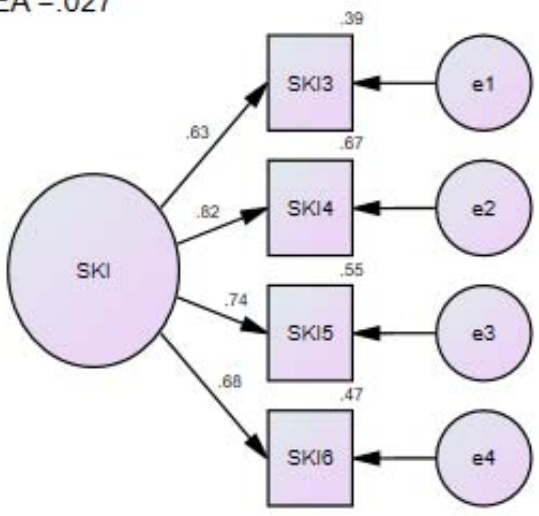

Figure 3.4: Initial measurement model for constructs of skill

There are four items (SKI3, SKI4, SKI5, SKI6) in the SKI construct. The descriptive summary and Interitem correlations values for items in SKI construct are depicted in Table 3.4.

The fit indices indicated a poor fit (CMIN/DF < 3.00, $\mathrm{CFI}<0.3$, and; RMSEA<0.08) in the Initial measurement model for SKI construct.
Then the final model of the SKI construct aligned with the data evidenced by the Normed Chisquare, CFI, and RMSEA were in the desired value (Chinna, 2013). Further, the factor loading of all the items was above .5, (Table 4.1) indicating adequate Individual item reliability (Hair, et al. 1995).

Table 4.3: Factor loading of all items skill

\begin{tabular}{|c|c|c|c|c|}
\hline & Estimate & S.E. & C.R. & P \\
\hline SKI3 & 1.000 & & & \\
\hline SKI4 & 1.155 & .094 & 12.291 & $* \star \star$ \\
\hline SKI5 & 1.063 & .090 & 11.790 & $\star \star \star$ \\
\hline SKI6 & 1.034 & .092 & 11.198 & $\star \star \star$ \\
\hline
\end{tabular}

\section{c) Shared values/Style}

There are four items (SVI1, SVI2, SVI3, SV14, and SVI5) in the SV construct. The descriptive summary and Inter-item correlations values for items in SV construct are depicted in Table 4.1.The Cronbach's alpha for SVI construct was 0.710, above the recommended cut-off 0.70 (De Vellis, 2003). The Inter item correlation matrix revealed (Table 1.3) the highest correlation values for $\mathrm{PE}$ construct items were more than 0.3 (Hair, et al, 1998). As a result, no items were removed from the SV construct.

The final model of the SV construct aligned with the data evidenced by the Normed Chi-square, CFI, and RMSEA was in desired value (Chinna, 2013). Further, factor loading of all the items was above .5, indicating adequate Individual item reliability (Hair, et al., 1995). 


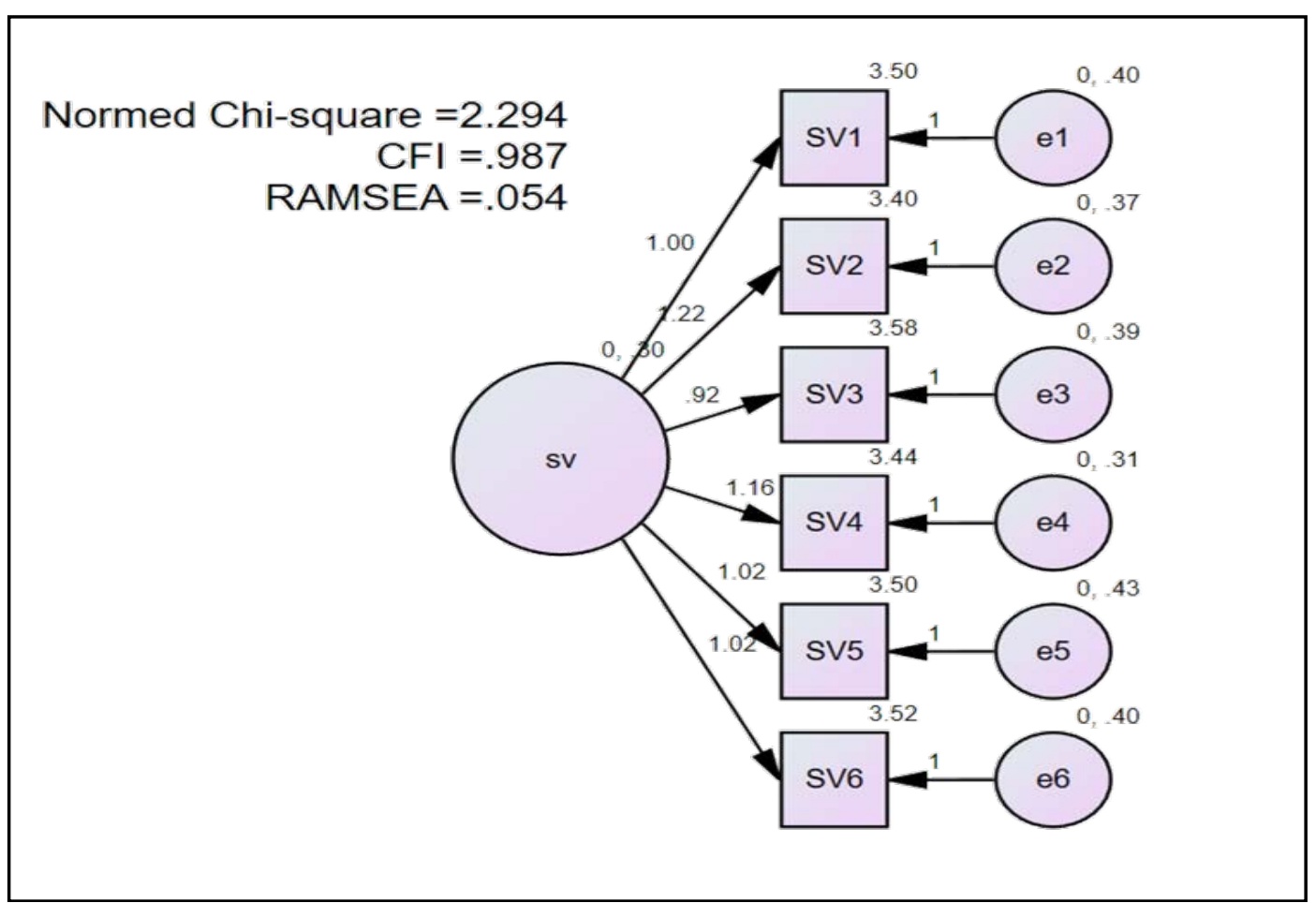

Figure 3.5: Final measurement model for constructs of SV

The figure 3.5, final model of the SV construct aligned with the data evidenced by the Normed Chisquare, CFI, and RMSEA was in desired value (Chinna, 2013). Further, factor loading of all the items was above .5 , indicating adequate Individual item reliability (Hair, et al1995).

The final model of the SV construct aligned with the data evidenced by the Normed Chi-square, CFI, and RMSEA was in desired value (Chinna, 2013). Further, factor loading of all the items was above .5, indicating adequate Individual item reliability (Hair, et al., 1995).

\section{Results of Testing the Hypotheses}

Considering the results of SEM, this section answers the hypotheses developed .Hypotheses were tested through the proposed final model of the study, which was developed by the final structural model (Figure 3.6). Summary conclusions for the 12 hypothesized relationships are provided in Table 4.6.

H1: There is a significant positive relationship between people strategy and organizational performance. Tests the relationship between the Independent variable of people strategy and the dependent variable of organizational performance. The results (Figure 3.6) show that there is a positive influence between people strategy and organizational performance $(\beta=0.15, p<$ 0.05).

H2: The relationship between staff and skills is moderated by people strategy.

H3: The relationship between shared value/style is moderated by people strategy. a) Testing the moderating effect of people strategy

Before testing the moderating effect, people strategy constructs were assessed with the internal consistency reliability (Cronbach's alpha), the descriptive summary and the inter-item correlation values. Each item in the construct was measured on a Likert scale of 1 to 5 , where a response of 1 indicates strong disagreement while a value of 5 indicates strong agreement to the statements. There are eight items in this construct (Appench -2A). The statements are formulated as positive. Cronbach's alpha was 0.916.

In this case, the hypothesis that the moderating effects of people strategy between skill, staff and shared value style is significant and supported. 


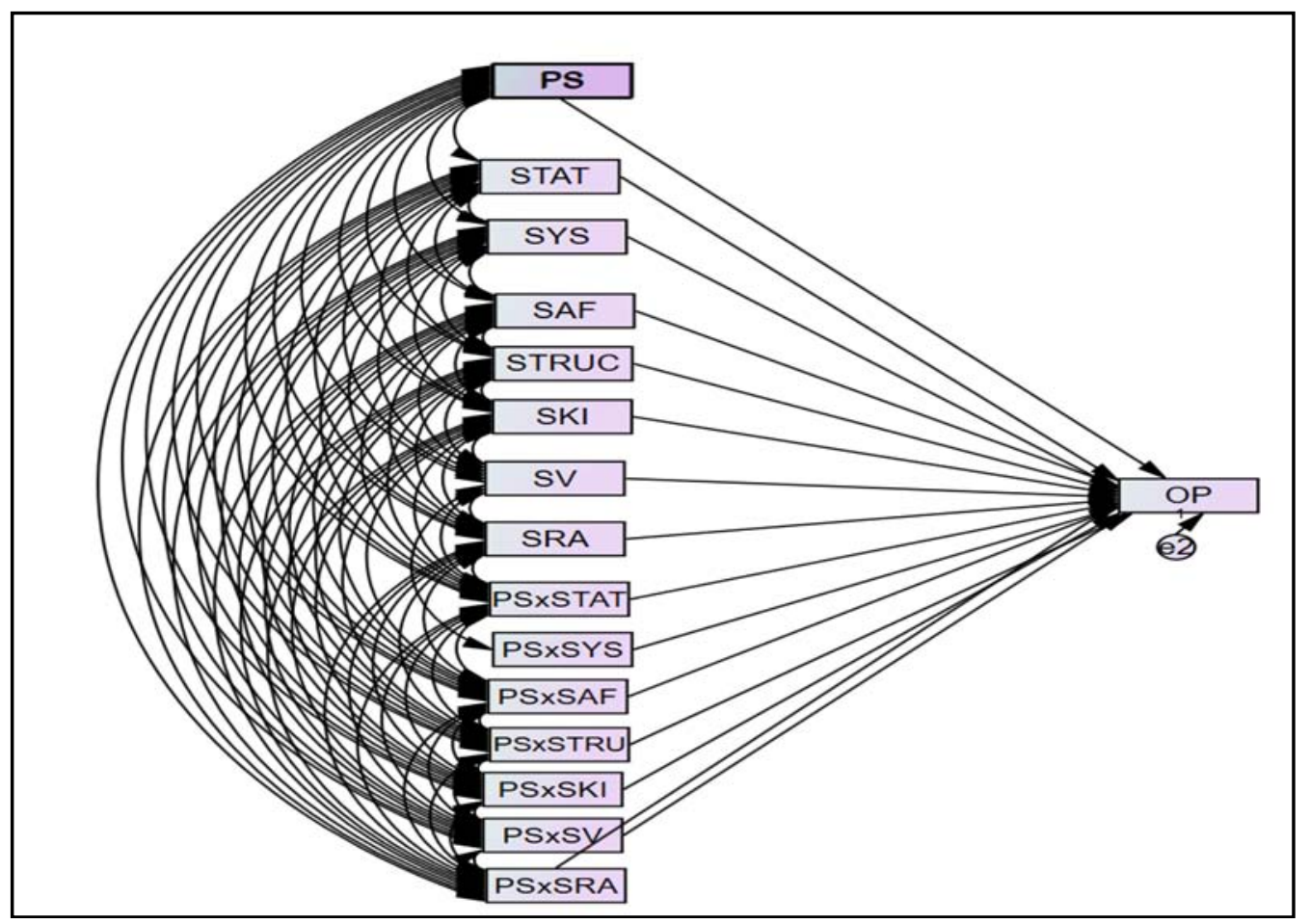

Figure 3.6: People strategy moderate skills in organizational performance to identify the impact of strategic HRM in insurance industry

The figure 3.6 depicts moderating effect of people strategy whereas constructs were assessed with the internal consistency reliability (Cronbach's alpha), the descriptive summary and the inter-item correlation values. Each item in the construct was measured on a
Likert scale of 1 to 5 , where a response of 1 indicates strong disagreement while a value of 5 indicates strong agreement to the statements. There are eight items in this construct. The statements are formulated as positive. Cronbatch's alpha was 0.916 .

Table 4.4: Moderating effect of people strategy on SKI-OP relationship

\begin{tabular}{|c|c|c|c|c|c|c|c|}
\hline & & & Estimate & S.E & C.R & $\mathrm{P}$ & Result \\
\hline $\begin{array}{l}\text { Organizational } \\
\text { Performance }\end{array}$ & 4 & Skill & 0.017 & 0.084 & .204 & $<.003$ & Supported \\
\hline $\begin{array}{l}\text { Organizational } \\
\text { Performance }\end{array}$ & 4 & Staff & 0.836 & .024 & .935 & .02 & Supported \\
\hline $\begin{array}{l}\text { Organizational } \\
\text { Performance }\end{array}$ & 4 & Shared values & 0.24 & .021 & .503 & .012 & Supported \\
\hline $\mathrm{H} 1$ & \multicolumn{6}{|c|}{$\begin{array}{l}\text { There is a significance positive relationship between peoples'strategy and } \\
\text { OP }\end{array}$} & Supported \\
\hline $\mathrm{H} 2$ & \multirow{2}{*}{\multicolumn{6}{|c|}{$\begin{array}{c}\text { The relationship between staff and skills is moderated by people strategy } \\
\text { The relationship between shared value and style is moderated by people } \\
\text { strategy }\end{array}$}} & Supported \\
\hline $\mathrm{H} 3$ & & & & & & & Supported \\
\hline
\end{tabular}

\section{Vi. Findings and Conclusions}

The main purpose is to highlight the discussion of research questions and hypotheses based on the conceptual framework. Then it endeavors to address the theoretical and practical implications, conclusions and suggestions of the study. The chapter concludes with recommendations for future research directions.

This study is an empirical research on influence of impact of moderating effect of people strategy on strategic human resource management functions on organizational performance in insurance industry of Sri Lanka. The results of the study would determine management implications and offer valuable recommendations to the insurance industry of Sri Lanka, in order to impact organizational performance through strategic HRM and people strategy.

At the outset a significant focus is shed on firm's performance between HR strategy and firm's outcomes (Armstrong, M., \& Brown, D., 2019). The main objective of the study was to investigate the relationship between SHRM practices, people strategy and their 
impact on organizational performance in insurance industry. The results further identify the SHRM practices which are most significant in achieving organizational human resources performance. Primary objectives of an insurance company would be to retain its existing employees as people of an organization would translate and contribute towards the profitability of an insurance company. Employee commitment not only warrants positive human formation and repeat organization performance and possibility with greater value in terms of superior customer service and also with other benefits such as cross buying intentions (Barana and Sophia, 2014).

\section{a) Summary of the Findings}

The study was intended to investigate and examine the impact of moderating effect of people strategy on strategic human resource management functions on organizational performance of insurance companies as an industry both life and non-life insurance companies. Study collect primary data by using questionnaire and while secondary data was collected by using secondary source like review various documents. The main important areas of the study concern include identification of the current situation of HRM functions in insurance companies, determination of relationship between SHRM and performance of insurance companies to examine the factors affecting effective implementation of SHRM functions in insurance companies.

\section{i. Staff}

This hypothesis examines the relationship between organizational performance and adoption and effective management of staff. The results showed that staff had the most potent effect on organizational performance of all the main determinants. The results are consistent with previous studies.

The enterprise is directly linked to the performance of those who work for that business. By the same token, under-achievement can be a result of work place failures. Because, hiring the wrong people or failing to anticipate fluctuations in hiring needs can be costly, it is important that conscious efforts are put into human resource planning (Biles \& Holmberg, 1980; Djabatey, 2012).

\section{ii. Skills}

This hypothesis examines the relationship between organizational performance and adoption toward employee skills. The results showed that employee skills had the most potent effect on organizational performance of all the main determinants. The results are consistent with previous studies as indicated. Riggio (2009) explained that skills development and development assets important as a subsystem embedded within the many operations of HR functions.

\section{iii. Shared Values/Style}

This hypothesis examines the relationship between organizational performance and adoption toward Shared Values. The results showed that Shared Values /Style had potent effect on of all the organizational performance main determinants. The results are consistent with previous studies.

Shared values/ super ordinate goals are described as guiding concepts and fundamental ideas around which a business and its performance is built (Peters \& Waterman, 1982). In management, the term refers to the degree to which a management team accepts and believes the company goals (Pinto et al., 1993).

The hypothesis examines the relationship between organizational performance and adoption toward shared values/style. The results showed that Shared Value/Style had the potent effect on organizational performance of all the main determinants. The results are consistent with previous studies. Hence the following hypothesis is established.

\section{iv. People Strategy}

This hypothesis examines the relationship between organizational performance and adoption of people strategy. The results showed that people strategy had the most potent effect on organizational performance of all the main determinants. The results are consistent with previous studies.

To improve firm performance and create competitive advantage, people strategy positively impact on organizational performance with the adoption of people strategy which tend to create a significant contribution on organizational performance (Delloitte, 2016), and this in turn becomes a great boost for further improvement on innovative people management practices (Noe et al., 2003; Youndt et al.,2004). According to Horngren (2000) and Anantharaman (2003), organizations link the maximization of performance with adoption people strategy practices (3Dimensional people strategy Byrne 2003).

\section{b) The relationship between staff skill is moderated by people strategy}

This hypothesis examines the relationship between staff skill is moderated by people strategy and adoption of staff skill. The results show staff skill is moderated by people strategy had the most potent impact on organizational performance of all the main determinants. The results are consistent with previous studies.

Recent theoretical studies in business strategy have indicated that firm competitive advantage could be generated from a firm's people factor through creating value in a manner that is rare and difficult for competitors to imitate (Barney, 2011). 
c) The relationship between staff shared value and style is moderated by people strategy

This hypothesis examines and establishes that recent theoretical studies in business strategy have indicated that firm competitive advantage could be moderated by firm's shared values and style could be moderated by people strategy with its underpinning HR policies and processes, that an organization develops and implements for managing its people to optimal effect. Every company should adapt a people strategy and simply aim to establish best practice in each of the $\mathrm{HR}$ policy areas. There have been attempts to describe people strategy as an internally coherent set of HR policies and practices. People strategy has proven to be both difficult and elusive. A firm might expect, there appears to be no one single "type" of people strategy with a set of HR policies and practices that can be adopted by organizations seeking to manage their people more strategically which drive towards a high performing business entity (Lynda Gratton and Catherine Truss, 2003; 2014).

\section{Vil. ReCOMMENDATIONS}

a) Staff

The cornerstone for motivation, reward and recognition is management capability. Skilled and experienced managers are able to clearly articulate what is expected from them and to ensure quality of output, whilst recognizing and praising staff's contribution. They are able to ensure that staffs are supported in their professional endeavors, understand how their role contributes to the corporate objectives and overall success of the organization.

Staff capability is the key to success and the roles played by managers and leaders in the insurance industry are paramount in the achievement of an improved staff experience. As such, insurance companies will have to commence development of key staff with proper People Management initiatives. Among such initiatives there can be HR.

b) Skills

- Recruitment and retention: there is a perception that external candidates are often favored over internal for vacancies so some staff look outside in order to progress.

- People in the right place - the right place operationally to make best use of their skills and the right place psychologically and emotionally, in terms of how inspired they feel by the Company and its mission.

- Psychometric Assessments for Recruitment \& Selection.

- Design psychometric testing process to be used for recruitment and promotions. This is a method that will be adopted for the measurement of the mind, thereby, giving the recruiters a better overall evaluation of candidates in order to secure the best fit for a job role responsibility.

c) Shared Values /Style

Employees should be able to link their everyday tasks and responsibilities to the values in the organization. Staff need to understand why and what they do is important.

- Build capacity of staff, integrate with work processes, enhance training and learning management systems,

- Develop leadership and management capabilities,

- Review leadership talent,

- Enhance the skills and capacities of national staff.

\section{References Références Referencias}

1. Abdullahi, M. S. (2018). Effect of training and development on employee's productivity among academic staff of Kano state polytechnic, Nigeria. Asian People Journal (APJ), 1(2), 264-286.

2. Abdullahi, M. S. (2018). Effect of training and development on employee's productivity among academic staff of Kano state polytechnic, Nigeria. Asian People Journal (APJ), 1(2), 264-286.

3. Abdullahi, M. S. (2018). Effect of training and development on employee's productivity among academic staff of Kano state polytechnic, Nigeria. Asian People Journal (APJ), 1(2), 264-286.

4. Agata, S., Tognazzo, S., Alducci, E., Matricardi, L., Moserle, L., Barana, D., \& Montagna, M. (2020). Segregation analysis of the BRCA2 c. $9227 \mathrm{G}>\mathrm{T}$ variant in multiple families suggests a pathogenic role in breast and ovarian cancer predisposition. Scientific Reports, 10(1), 1-6.

5. Amershi, S., Weld, D., Vorvoreanu, M., Fourney, A., Nushi, B., Collisson, P., ... \& Horvitz, E. (2019, May). Guidelines for human-Al interaction. In Proceedings of the 2019 chi conference on human factors in computing systems (pp. 1-13).

6. Amoako-Gyampah, K., \& Salam, A. F. (2004). An extension of the technology acceptance model in an ERP implementation environment. Information \& management, 41(6), 731-745.

7. Armstrong, M. (2009). Armstrong's handbook of performance management: An evidence-based guide to delivering high performance. Kogan Page Publishers.

8. Asimakopoulos, I., Samitas, A., \& Papadogonas, T. (2009). Firm-specific and economy wide determinants of firm profitability: Greek evidence using panel data. Managerial Finance.

9. Babcock-Roberson, M. E., \& Strickland, O. J. (2010). The relationship between charismatic leadership, work engagement, and organizational citizenship behaviors. The Journal of psychology, 144(3), 313-326. 
10. Barney, J. B., KetchenJr, D. J., \& Wright, M. (2011). The future of resource-based theory: revitalization or decline?. Journal of management, 37(5), 12991315.

11. Bhui, K., Warfa, N., Edonya, P., McKenzie, K., \&Bhugra, D. (2007). Cultural competence in mental health care: a review of model evaluations. BMC health services research, 7(1), 1-10.

12. Choo, W. Y., Walsh, K., Chinna, K., \& Tey, N. P. (2013). Teacher reporting attitudes scale (TRAS) confirmatory and exploratory factor analyses with a Malaysian sample. Journal of interpersonal violence, 28(2), 231-253.

13. Combs, J., Liu, Y., Hall, A., \& Ketchen, D. (2006). How much do high-performance work practices matter? A meta-analysis of their effects on organizational performance. Personnel psychology, 59(3), 501-528.

14. Darroch, J. (2003). Developing a measure of knowledge management behaviors and practices. Journal of knowledge management.

15. De Vellis, J. C. (2003). Patenting industry standards: balancing the rights of patent holders with the need for industry-wide standards. AIPLA QJ, 31, 301.

16. Djabatey, E. N. (2012). Recruitment and Selection Practices of Organisations: A Case Study of HFC Bank (Gh) Ltd (Doctoral dissertation).

17. Djabatey, E. N. (2012). Recruitment and Selection Practices of Organisations: A Case Study of HFC Bank (Gh) Ltd (Doctoral dissertation).

18. Ekwoaba, J. O., Ikeije, U. U., \& Ufoma, N. (2015). The Impact of Recruitment and Selection Criteria on Organizational Performance.

19. Ekwoaba, J. O., Ikeije, U. U., \& Ufoma, N. (2015). The Impact of Recruitment and Selection Criteria on Organizational Performance.

20. Fierro, L., Gaddis, M., Kinney, M., Reed, J., Kirkwood, B., Greene, M., ...\& Deloitte Consulting, L. L. P. (2016). Implementation pilot for twodimensional (2D) vaccine barcode utilization: summary report.

21. Fung, W. W., Sham, I., Yuan, G., \& Aamodt, T. M. (2007, December). Dynamic warp formation and scheduling for efficient GPU control flow. In 40th Annual IEEE/ACM International Symposium on Microarchitecture (MICRO 2007) (pp. 407-420). IEEE.

22. Gamage, P. N., \& Imbulana, L. (2013). Training and development and performance of employees: Evidence from Sri Lanka Telecom. International Journal of Marketing, Financial Services \& Management Research, 2(9), 12-24.

23. Gannile, C., AbYajid, M. S., Khatibi, A., \& Azam, S. F. (2020). IMPACT OF MEASUREMENT DRIVEN HR STATISTICS ON STRATEGIC HUMAN RESOURCE MANAGEMENT FUNCTIONS ON ORGANIZATIONAL PERFORMANCE IN
INSURANCE INDUSTRY. European Journal of Social Sciences Studies, 5(3).

24. Gratton, L., \& Truss, C. (2003). The threedimensional people strategy: Putting human resources policies into action. Academy of Management Perspectives, 17(3), 74-86.

25. Hanafi, H. M. (2019). IMPACT OF EMPLOYEE COMPETENCIES ON SERVICE PERFORMANCE: THE MEDIATING ROLE OF CUSTOMER EXPERIENCE (Doctoral dissertation, Sudan University of Science and Technology).

26. Hanafizadeh, P., \& Ravasan, A. Z. (2011). A McKinsey 7S model-based framework for ERP readiness assessment. International Journal of Enterprise Information Systems (IJEIS), 7(4), 23-63.

27. Hussain, I. (2015). Macro economy and profitability of insurance companies: a post crisis scenario in Pakistan. Pakistan business review, 17(2), 243-263.

28. Jaakola, V. P., Griffith, M. T., Hanson, M. A., Cherezov, V., Chien, E. Y., Lane, J. R., ... \& Stevens, R. C. (2008). The 2.6 angstrom crystal structure of a human A2A adenosine receptor bound to an antagonist. Science, 322(5905), 1211-1217.

29. Kenny S, V. (2019). Employee productivity and organizational performance: A theoretical perspective.

30. Kim, Y., Lee, Z., \& Gosain, S. (2005). Impediments to successful ERP implementation process. Business process management journal.

31. Kogo, P. K., \& Kimencu, L. (2018). Organizational capabilities and performance of insurance companies in Nairobi city county, Kenya. International Academic Journal of Human Resource and Business Administration, 3(1), 126-149.

32. Kryscynski, D., \& Ulrich, D. (2015). Making strategic human capital relevant: A time-sensitive opportunity. Academy of Management Perspectives, 29(3), 357369.

33. Marimuthu, M., Arokiasamy, L., \& Ismail, M. (2009). Human capital development and its impact on firm performance: Evidence from developmental economics. Journal of international social research, 2(8).

34. Mastrangelo, M. E., Weyland, F., Villarino, S. H., Barral, M. P., Nahuelhual, L., \& Laterra, P. (2014). Concepts and methods for landscape multifunctionality and a unifying framework based on ecosystem services. Landscape Ecology, 29(2), 345-358 